\title{
The Modified Impact of CEO Characteristics on the Relationship Between Internal Audit Quality and Firms Performance in The Jordanian Corporations
}

\author{
Ali Mustafa Magablih \\ Irbid National University - Jordan
}

Received: Dec. 8, 2021 Accepted: Jan. 12, 2022 Online published: Feb. 13, 2022

doi:10.5296/jpag.v12i1.19549ＵRL: https://doi.org/10.5296/jpag.v12i1.19549

\begin{abstract}
The study aim to identify the modified impact of the characteristics of the CEO on the relationship between the quality of internal auditing and the performance of the Jordanian corporations. The study population consisted of Jordanian corporations listed on Amman stock exchange. In order to achieve the objective of the study they adopted the descriptive analytical approach, by developing the questionnaire that was distributed. The study populations consist of all Jordanian corporations and 250 questioners was distributed in the study sample consisting of financial manager, internal auditor and heads of accounting department 206 questionnaire were received of which 183 were valid for analysis. Used the SPSS program in analysis the study tool in addition to some descriptive statistical methods (arithmetic, means and standard deviation).

The study reached a number of results, most important of which are there is statistically significance level the quality of internal audit and positively effect the performance of Jordanian corporations, in addition the characteristic of the CEO passively effect the reaction ship between the quality of internal auditing and the performance of the Jordanian corporations. The study also came out with a number of recommendations, the most important of which were the need to strength and improving the internal audit function in Jordanian companies, increasing its quality, and focusing more on the characteristics and attributes of the CEO. As well as the need for companies to keep abreast of developments and techniques related to internal auditing and use them in internal audit operations in Jordanian corporations.
\end{abstract}

Keywords: internal audit quality, CEO characteristics, corporate performance, Jordanian corporations 


\section{Introduction}

Corporate performance is a key metric for investors, government, and regulators. By evaluating the performance of the company, investors decide to invest in the company or keep their investment, so companies use some characteristics such as the quality of internal audits to reduce the problems of their agency, and thus improve their performance. During the credit crunch, the lack of audit quality was one of the main causes of many corporate scandals around the world, and to improve company performance. There are some indicators such as the quality of internal audit. Recently, researchers have examined the direct effects of companies and the characteristics of internal audit quality and company performance. In line with agency theory, which is a contract under which a person (agent) is appointed by another person or number of persons to perform some service on their behalf? Conflicts may arise when the agent and principal have different and incompatible interests. The internal audit function can address this issue when it is independent and has the support of senior management. Previous studies found that audit quality reduces agency costs and enhances company performance, and is also consistent with the Signaling Theory, which indicates that strong and good corporate governance requires high audit quality. On the other hand, one of the key factors to becoming a reliable and trustworthy company in a select group must have reliable financial statements and efficient reporting processes. It is not enough to hire a competent management team for companies to gain the confidence of their shareholders.

The quality of internal audit plays a role in helping companies to issue reliable financial statements, which leads to better performance in companies listed in various stock markets.

Audit quality is vital for every organization to achieve effective resource management and lead to improved performance as a major implementation strategy of the accounting system, and helps management verify the functioning of each department within the company as a whole. The quality of the audit worldwide ensures that the quality of the financial statements or reports of companies listed on the stock exchanges of any country is achieved. The quality of internal audit reflects the quality of financial reports or information held by institutions to create confidence among stakeholders, and also reflects the efficiency and credibility of the audit department in the institution within the institution's practices as part of the corporate governance structure in the company's management and practices.

The impact of internal audit quality on a company's performance has an impact on the agency's relationship with the company, and this has not been extensively studied by most researchers in emerging economies, although audit services have been well recognized as one of the mechanisms used to mitigate the agency problem that exists mostly between corporate management and shareholders.

The audit service is just another component of the corporate governance structure and an important aspect of the regulatory system to protect the interests of shareholders and serve other stakeholders in public companies around the world. Thus, the internal audit has become an important role in preserving the assets of companies and maximizing the wealth of owners through its role in developing work activities in organized 
Nowadays, competition is increasing, so there is a greater need to understand complex customer demand

Nowadays, competition is increasing, thus there is greater need to understand complex customer demand. Moreover, shareholders and investors demand the highest profit margins. Therefore, the importance of having a well-organized board of directors is increasing day by day. Many researches have been done on why and how the characteristics of a CEO are important to a company. The CEO is one of the major players in the corporate sector. By sitting at the top of corporate management teams, CEOs can direct companies to actively pursue opportunities and control corporate structures and strategies). Specifically, CEOs make important and strategic decisions that can affect the performance of their companies. Claimed that the most important determinant of a company's survival and success depends on the performance and quality of the company's top managers.

It is clear that the characteristics of the CEO have been included among many factors that affect companies, as reported in several studies. The personality of the CEO is likely to have an important influence on the success of the company). The focus of this thesis is on the characteristics of the CEO since the position of CEO is very important in the management hierarchy. Therefore, this thesis sheds light on the characteristics of CEOs and their impact on the relationship between the quality of internal auditing and corporate performance. Thus, it is important that this message assist researchers in understanding the roles of CEOs in companies

\section{The problem of the study:}

Previous research indicates that internal audits can have a positive impact on corporate governance and performance). Despite the widespread acceptance of the benefits of internal auditing, there is relatively little documented empirical research on the role of internal audit quality o corporate performance. Moreover, the nature of the context of each country may affect the quality of application of the International Professional Standards for Internal Auditing. In this study, Jordan is a developing country with a small economy. Most Jordanian companies are mainly owned by families who tend to have a few large shareholders who control their executive management, in addition to many small shareholders. In general, the nature of Jordanian companies and their system of governance makes the application of the internal audit function different from those in more developed countries which are characterized by companies that tend to be significantly larger and have more sophisticated internal audit and corporate governance. Hence the need to study the impact of CEO characteristics on the relationship between internal audit quality and corporate performance, in addition, the nature of the economic market in Jordan and the markets of developing countries requires conducting more studies on the quality of auditing and what is related to it.

From here, the problem of this study appears in the importance directed to the characteristics of the CEO and the lack of interest in some literature in this importance, as the CEO is an essential component of companies of all kinds and areas of specialization, and contributes significantly to improving the ability of organizations to compete in the presence of a highly competitive environment. 


\section{Study Questions:}

This study came to clarify the modified effect of the CEO's characteristics on the relationship between the quality of internal auditing and the performance of Jordanian corporations by answering the following question:

1. Is there an impact of the quality of internal auditing on the financial performance of Jordanian corporations?

2. Is there an impact of the quality of internal auditing on the non-financial performance of Jordanian corporations?

3. Is there an impact of the quality of internal auditing on the financial performance of Jordanian corporations in light of the characteristics of the CEO?

4. Is there an impact of the quality of internal auditing on the non-financial performance of Jordanian corporations in light of the characteristics of the CEO?

\section{Objectives of the study:}

In light of the study problem presented in the previous paragraph, the main objective of the research is to identify the modified effect of the characteristics of the CEO on the relationship between the quality of internal auditing and the performance of Jordanian corporations?

This is done through the following:

1) A statement of the impact of the quality of internal auditing on the financial performance of Jordanian corporations.

2) A statement of the impact of the quality of internal auditing on the non-financial performance of Jordanian corporations.

3) Statement of the impact of internal audit quality on the financial performance of Jordanian corporations in light of the characteristics of the CEO.

4) Statement of the impact of internal audit quality on the non-financial performance of Jordanian corporations in light of the characteristics of the CEO.

\section{Importance of the study}

The theoretical importance of this study highlights its support for theoretical studies and research in the field of internal audit quality and its impact on corporate performance, in addition to the impact of the CEO's characteristics on the relationship between internal audit quality and corporate performance. A new addition to the Arabic library, in addition to all researchers who want to continue their research in this field in the future

\section{Research Hypotheses:}

In order to answer the study problem and achieve its objectives, the following nihilistic hypotheses were formulated:

The first main hypothesis:

Ho1: There is no impact of the quality of internal auditing on the financial performance of Jordanian corporations. 
The second main hypothesis:

Ho2: There is no impact on the quality of internal auditing on the non-financial performance of Jordanian corporations.

The third main hypothesis:

Ho3: There is no impact on the quality of internal auditing on the financial performance of Jordanian corporations in light of the characteristics of the CEO.

The Fourth main hypothesis:

Ho4: There is no impact of the quality of internal auditing on the non-financial performance of Jordanian corporations in light of the characteristics of the CEO.

\section{Previous studies}

Khalil and Maghrabi study (2016) entitled: "The effect of patterns of ownership structures and characteristics of the board of directors on the quality of the online financial report on companies listed on the Egyptian Stock Exchange.

This study aimed to demonstrate the impact of the patterns of ownership structures and the characteristics of the board of directors on the quality of the financial report via the Internet, after the decision of the Board of Directors of the Egyptian Financial Supervisory Authority No. 11 dated 1/29/2014 regarding the rules for listing and delisting securities in the Egyptian Stock Exchange Article No. (6) Item) e) which relates to the obligation of the company requesting registration to establish an electronic website on the international information network as soon as any of the securities are listed on the stock exchange and before trading begins on them. To measure the quality of the online financial report, it consists of (81) items divided into two groups: content and presentation. In choosing the research hypotheses, the researchers relied on the use of the Pearson correlation coefficient and the progressive multiple linear regression models to measure the relationship between the quality indicator of the online financial report and the characteristics of the board of directors and ownership structures. 2012.

Among the findings of the study is that the board of directors plays a key role as a financial audit mechanism, and that one of the most important motives for companies to publish the financial report via the Internet is the personal cost and time taken to distribute information, and that the increase in levels of administrative ownership has led to increase the convergence of interests and the reduction of information asymmetry may lead to increased attention to the quality of financial reports

\section{Hayrat study (2016) entitled: "The impact of the characteristics of the board of directors on the quality of auditing in industrial corporations (applied study)}

This study aimed to show the impact of the characteristics of the board of directors on the quality of auditing in the Jordanian industrial corporations. The announced annual meetings, while the quality of the audit provided to the industrial companies listed on the Amman Stock Exchange was identified by measuring it with the size of the audit office, the work retention period, the value of the audit fees, and linking with international offices. 


\section{Mll Macrothink}

Journal of Public Administration and Governance ISSN 2161-7104 2022, Vol. 12, No. 1

The study community is represented by the corporations that belong to the industrial sector listed on the Amman Stock Exchange for the year 2014, abo industrial companies. It has a link with international offices and therefore it is expected that the quality of the audit will increase because of that link

\section{Al-Shahed and Al-Kurdi study (2018) entitled: "The impact of the characteristics of the board of directors and audit committees on the quality of profits, evidence from Jordanian commercial banks."}

This study aimed to explore the relationship between the characteristics of the board of directors and the audit committee, and income smoothing as a measure of profit quality in Jordanian commercial banks. The study sample consisted of all 31 Jordanian commercial banks listed on the Amman Stock Exchange with a number of 19 views for the period from 2007 to 2013. The results of the study showed a statistical relationship between the other variables (the class of ownership, the size of the audit committee, the number of audit meetings, the number of audit committee meetings, Board of Directors), and the quality of profits. The study recommended searching for other characteristics of audit committees, such as the independence of audit committees, experience, and scientific competence, and nothing may have an impact on the quality of profit.

Mubaraki and Bosna study (2018), entitled: "The impact of the board's characteristics on the financial performance of the institution (case study: a sample of French institutions listed in the $\mathrm{CaC40}$ index).

This study aimed to test the impact of the characteristics of the board of directors on the financial performance of the French companies listed on the stock exchange within the index (CaC40), during the period from 2015 to 2017. Financial indicators using two important indicators are the rate of return on assets and the rate of return on equity (ROA).

The study concluded that there is a significant relationship between the independence of the Board of Directors and the CEO and the financial performance of French institutions, as well as the existence of a negative moral relationship between the duplication of the CEO and the financial performance of the French institutions on the other hand, and the study also concluded that there was no significant effect of the size of the board of directors and the number of its meetings on the financial performance of the French institutions under study

A study (Ghazi Al-Otaibi, 2018) entitled: "The impact of the CEO's traits on the financial performance of public institutions in Kuwait."

This study aimed to assess the impact of the CEO's attributes on the financial performance of public companies in Kuwait. To test it by applying it to a sample of 35 public institutions in the period 2012-2016. The study used two measures of financial performance, namely profit distribution and debt ratio, while the independent variables included four characteristics: age, gender, number of years of appointment of the CEO, and education level, while the control variables were fixed assets ratio and debt ratio. Including company size \& using unit root tests such as (Dickey - Fuller) and (Phillips Peron) as well as multiple regression analysis, the results of the study concluded that there was no statistically significant effect at a significant 
level (0.05) for the gender of the CEO, the age of the CEO and the educational level on the financial performance in Kuwaiti public investment companies are measured by the percentage of dividends, with a statistically significant effect at a significant level (0.05) on the duration of the position of the CEO, the percentage of fixed assets, and the size of the company's assets on the financial performance of the Kuwaiti public. Investment companies, measured by the percentage of dividends. The results of the study concluded that at the significance level (0.05) for the term of office of the CEO, the level of education and the percentage of fixed assets, there was no statistically significant effect on the financial performance of Kuwait and public investment companies, as measured by a percentage of debt, while there is a statistically significant effect at the significance level (0.05).

The age of the CEO, the gender of the chairman of the board of directors, and the size of the company's assets in relation to the financial performance of Kuwaiti public investment companies, as measured by the debt ratio. The study recommended encouraging Kuwaiti companies to follow the best practices regarding the characteristics of the CEO because of their impact on the value of the company in resolving disputes and conflict of interests in it, and a comparative study of the characteristics of the CEO with regard to the financial performance between Kuwaiti investment companies and joint stock companies from one country or another. And the need to pay attention to applied studies that measure the characteristics of the executive director in relation to financial policy over multiple periods over time to determine the extent to which the characteristics of the executive director have evolved in Kuwaiti public properties.

A study (Fathi Al-Juwasmi, 2018) entitled "The characteristics of the board of directors and their impact on financial performance", an analytical study of the banking sector in the Saudi market.

This study aimed to know the impact of the characteristics of the board of directors on the financial performance of the banking sector in the Saudi market. The application was applied to a sample of (11) banks registered in the Saudi market from 2016 to 2018. The researcher relied on the descriptive analysis approach, analysis of the correlation between variables and multiple regression analysis. The study concluded that in terms of return, there is a positive and statistically significant relationship between the CEO of the royal family; the relationship was negative between the return on capital and return on equity, the size of the board of directors, the number of board meetings, and the percentage of independent board members and the share of ownership of the head of the department. And its shares are traded in the Saudi stock market in light of corporate governance in order to maintain the best ratio to apply corporate governance rules to ensure the continued positive impact of corporate governance rules on financial performance. And the need for the state and specialized bodies such as the Saudi Capital Market Authority to intervene to issue laws and regulations to impose penalties and penalties on banks and other companies for non-compliance with governance regulation

Bani Atta's study (2019) entitled: "The characteristics of the board of directors and their impact on financial performance: An applied study on industrial companies listed 
on the Amman Stock Exchange."

This study aimed to demonstrate the impact of the characteristics of the board of directors and their impact on financial performance through an applied study on industrial companies listed on the Amman Stock Exchange, as the board of directors has characteristics that have a clear role in carrying the board of directors to many burdens in order to play its role in protecting the rights of all dealers with the company and from then the nature of the board of directors consisting of the CEO had a clear and main role in the success of the institutions, by relying on many of the characteristics of the board of directors that guarantee the independence of the CEO and members of the board of directors. This study was applied to a number of industrial companies listed on the Amman Stock Exchange, which amount to 22 industrial companies. The study reached its conclusions, including that the characteristics of the board of directors play an important role in the efficiency of financial management, its quality and development, and the transparency and continuity of profits

\section{A study (2016, Hsueh - En Hsu) entitled:}

\section{The Relationship between Board Characteristics \& Financial Performance (SEO)}

This study examines the relationship between board characteristics and the financial performance of 223 US companies making initial public offerings from 2000 to 2002. Boards of directors of 223 US companies making initial public offerings from 2000 to 2002. Board characteristics include the independence of the board (ie the boards they control outsiders), the board of directors includes the independence of the board of directors (i.e. boards dominated by outsiders), the quality board (i.e. board experience and educational background) and venture capital managers. Financial performance is measured by Tobin's Q as the sum of the market value of shares, book value of preferred shares, and book value of total debt divided by the book value of the company's assets. A sample of companies is obtained from the Thompson Financial SDC database. The empirical results show that the independence of the board of directors is negatively related to the company's performance. As expected, the quality of the board of directors is positively correlated with the performance of the company. As expected, the quality of the board of directors is positive for the company's performance. It is considered positive management and is positively related to the company's performance. However, there is no evidence that venture capital managers or company performance. This is why venture capital managers positively correlate with financial performance, networked financial performance

\section{A study (2017, Abdelmoneim.elal)}

The effect of the characteristics of the board of directors on the period of issuing the auditor's report, applied studies

This study aimed to indicate the impact of the characteristics of the board of directors on the period of issuing the auditor's report, and the sample of the study was represented in the Jordanian joint stock companies during the period 2011-2013. Therefore, the use of cumulative regression analysis to measure the relationship between the variables, as the suitability of the model was confirmed through the test of normal distribution, autocorrelation, 
unit root test and the instability of time series. Managing the company and allocating the time necessary to carry out its work with integrity and transparency in the interest of the company, its goals and objectives. The auditor's report also entails mentioning important matters taken by the general assembly of shareholders, the most important of which is whether or not the members of the board of directors express their liability, as well as the appearance of an impact on the number of external board members, the percentage of external board members, and the number of members who have duplication of duties over the issuance period.

\section{A study (2017, Norman Mohd Saleh) entitled:}

"The association between CEO characteristics, internal audit quality \& risk management implementation in the public sector"

This study examines the relationships between the characteristics of the CEO and the implementation of risk management in public sector institutions in Malaysia. In this study, two personality traits of CEOs were examined: (1) a locus of control, and (2) a tendency to take risks. In addition, this study also examines the role of internal audit quality as a mediator of the relationship between the $\mathrm{CEO}$ and the implementation of risk management. The data were obtained from surveys conducted on the chief executives of federal and state legal agencies in Malaysia. 55 samples were analyzed using hierarchical multiple regression analyses. This study found that only the CEO's inclination to take risks is positively related to the implementation of risk management. However, internal audit quality has been found to facilitate the relationship between the position of chief control officer and the implementation of risk management. The results indicate that appointing a $\mathrm{CEO}$ with the right attributes, i.e. risk bias, and improving the quality of internal audit can help government agencies to accelerate risk management activities within their organization.

\section{The study population and its sample}

The study population consisted of all Jordanian corporations, according to the location of the Amman Financial Market. Questionnaires were distributed in the electronic form to the aforementioned employees, i.e. a total of (250) questionnaires, and (206) questionnaires were retrieved, of which (183) were valid for analysis.

\section{Study Tool}

The questionnaire constitutes the study tool and the first basic step for collecting data related to the study variables. It precedes the statistical analysis process and consists of a set of questions that clarify the study variables. The questionnaire was prepared, built and developed based on previous Arab and foreign studies, theses and scientific research. The questionnaire consisted of two parts; the first section included personal data, while the second section included questions about the study variables 5 Test the

\section{testing the stability of the study tool}

The researcher tested the reliability of the tool used to measure the variables it contains by using Cronbach's alpha coefficient test, where the result of the scale is statistically acceptable if the value of Cronbach's alpha is greater than $(0.70)$, and the closer the value is to $100 \%$, this indicates a higher degree of stability for the study tool, given the data provided in Table. 
The Cronbach's alpha coefficient was measured for the study variables and their dimensions and for the study tool as a whole to determine the consistency of the answers. This is as follows values of the internal consistency coefficient for the items of the study tool

\begin{tabular}{|c|c|c|}
\hline No. & The dimension & alpha value \\
\hline 1 & CEO Characteristics & 0.866 \\
\hline 2 & Efficiency & 0.817 \\
\hline 3 & Independence & 0.815 \\
\hline 4 & Scope of internal audit work & 0.831 \\
\hline 5 & Financial performance & 0.776 \\
\hline 6 & Non-financial performance & 0.769 \\
\hline $\mathbf{7}$ & all paragraphs & $\mathbf{0 . 9 3 9}$ \\
\hline
\end{tabular}

We note that the values of the internal consistency coefficient Cronbach's alpha for the elements of the study tool ranged between $(0.769-0.866)$, and its value for all paragraphs was (0.939), and therefore all values are greater than (0.70), and this is an indication of the consistency between the paragraphs of the study tool and the reliability of the study tool and the possibility of reliability to perform statistical analysis.

\section{Statistical Processing}

The researcher used the following statistical methods: The statistical package for social sciences SPSS was used in the following different statistical analyses:

1) Descriptive statistics: frequencies, percentages, arithmetic means, and standard deviations were used to provide a comprehensive description of the degree of agreement of the study sample to the various items.

2) Descriptive statistics procedures through percentages, frequencies, arithmetic means and standard deviations.

3) The internal stability coefficient (Cronbach's alpha) to measure the stability of the study tool, which is the questionnaire.

4) Multiple linear correlation test.

5) Simple and hierarchical linear regression.

6) The relative importance was determined according to the following formula and according to the five-point scale for the alternatives to answer each paragraph.

Where the number of levels is: Low, Medium, High

1. Low level if arithmetic mean of $1.0 \geq$ mean score $\leq 2.33$

2. Intermediate level if the arithmetic mean of $2.34 \geq$ mean score $\leq 3.67$

3. High level if it reaches an arithmetic mean of $3.68 \geq$ mean score $\leq 5.00$

\section{Description of the characteristics of the study sample}

This part includes a description of the definition and demographic characteristics of the study sample, which are: (practical experience, educational qualification, specialization, job title, and accounting certificates). In order to describe the characteristics of the study 
sample, the frequencies and percentages of demographic variables for the study sample were found as follows:

Years of experience

Distribution of sample members according to the variable years of experience

\begin{tabular}{|c|c|c|c|}
\hline The variable & Category & Repetition & \% \\
\hline Years of experience & Less than 3 years old & 8 & 4.4 \\
\cline { 2 - 4 } & From 3 - less than 6 years & 50 & 27.3 \\
\cline { 2 - 4 } & From 6 - less than 9 years old & 87 & 47.5 \\
\cline { 2 - 4 } & 9 years and over & 39 & 20.8 \\
\cline { 2 - 4 } & Total & 183 & $100 \%$ \\
\hline
\end{tabular}

We notice from Table that the sample members with experience (6 - less than 9 years) made up the largest percentage, which amounted to $(47.5 \%)$, and this indicates that the managers of Jordanian corporations have the expertise necessary to take over positions and perform the duties assigned to them.

\section{Academic Qualification}

Distribution of the sample members according to the educational qualification variable

\begin{tabular}{|c|c|c|c|}
\hline The variable & Category & Repetition & \% \\
\hline Academic & 12 & 6.6 \\
\cline { 2 - 4 } Qualification & Diploma & 126 & 68.9 \\
\cline { 2 - 4 } & Bachelor's & 38 & 20.8 \\
\cline { 2 - 4 } & Master's & 7 & 3.8 \\
\cline { 2 - 4 } & PhD & 183 & $100 \%$ \\
\hline
\end{tabular}

We note that holders of a bachelor's degree made up the largest percentage, amounting to (68.9\%), and this is consistent with the general trend in Jordanian shareholding companies to employ bachelor's holders as a minimum. We also note that holders of diploma and higher certificates made up the rest of the study sample, and this indicates that managers in industrial companies have the necessary knowledge.

Scientific specialization

Distribution of sample members according to the variable of scientific specialization

\begin{tabular}{|c|c|c|c|}
\hline The variable & Category & Repetition & \% \\
\hline \multirow{2}{*}{$\begin{array}{c}\text { Scientific } \\
\text { specialization }\end{array}$} & Accounting & 48 & 26.2 \\
\cline { 2 - 4 } & Finance and Banking Science & 49 & 26.8 \\
\cline { 2 - 4 } & Economy & 86 & 47 \\
\cline { 2 - 4 } & Total & 183 & $100 \%$ \\
\hline
\end{tabular}

We note that the sample included all economic, accounting and banking disciplines. 


\section{Job title}

Distribution of sample members according to job title variable

\begin{tabular}{|c|c|c|c|}
\hline The variable & Category & Repetition & \% \\
\hline $\begin{array}{c}\text { Academic } \\
\text { Qualification }\end{array}$ & Financial Manager & 32 & 17.5 \\
\cline { 2 - 4 } & Internal Audit Manager & 46 & 25.1 \\
\cline { 2 - 4 } & Internal Auditor & 71 & 38.8 \\
\cline { 2 - 4 } & $\begin{array}{c}\text { Head of accounts } \\
\text { department }\end{array}$ & 34 & 18.6 \\
\cline { 2 - 4 } & Total & 183 & $100 \%$ \\
\hline
\end{tabular}

We notice from Table (7) and Figure (5) that the sample members were distributed among all the nomenclature

\section{Professional certificates}

Distribution of sample members according to the variable of professional certificates

\begin{tabular}{|c|c|c|c|}
\hline The variable & Category & Repetition & \% \\
\hline \multirow{2}{*}{$\begin{array}{c}\text { Professional } \\
\text { certificates }\end{array}$} & CPA & 39 & 21.3 \\
\cline { 2 - 4 } & JCPA & 42 & 23.0 \\
\cline { 2 - 4 } & CMA & 77 & 42.1 \\
\cline { 2 - 4 } & CIA & 25 & 13.7 \\
\cline { 2 - 4 } & Total & 183 & $100 \%$ \\
\hline
\end{tabular}

We notice that the sample members hold various professional certificates.

\section{Analysis of study data}

The arithmetic averages, relative deviations, and relative importance were relied upon in describing the study variables, and the results were as follows:

\section{Description of the independent variables: the quality of the internal audit}

\section{Efficiency}

Arithmetic averages and standard deviations Rank and relative importance of competency clauses 


\begin{tabular}{|c|l|c|c|c|c|}
\hline$\#$ & \multicolumn{1}{|c|}{ Paragraph } & SMA & $\begin{array}{c}\text { Standard } \\
\text { Deviation }\end{array}$ & Rank & $\begin{array}{c}\text { Relative } \\
\text { importance }\end{array}$ \\
\hline 1 & $\begin{array}{l}\text { The internal auditor performs } \\
\text { his work in a correct and } \\
\text { sound manner }\end{array}$ & 4.06 & .664 & 2 & High \\
\hline 2 & $\begin{array}{l}\text { All available resources and } \\
\text { funds are exploited in order to } \\
\text { obtain the greatest possible } \\
\text { benefit from the internal audit } \\
\text { process. }\end{array}$ & 4.01 & .719 & 4 & High \\
\hline 3 & $\begin{array}{l}\text { A comparison is made between } \\
\text { the achieved goals and the } \\
\text { planned goals by the internal } \\
\text { auditor }\end{array}$ & 3.96 & .759 & 7 & High \\
\hline 4 & $\begin{array}{l}\text { The experience of the internal } \\
\text { auditor helps to improve the } \\
\text { quality of internal auditing }\end{array}$ & 4.03 & .702 & 3 & High \\
\hline 5 & $\begin{array}{l}\text { The internal auditor uses } \\
\text { accounting software that } \\
\text { primarily improves the quality } \\
\text { of internal auditing }\end{array}$ & 3.98 & .781 & 5 & High \\
\hline 6 & $\begin{array}{l}\text { Professional certificates } \\
\text { support the efficiency of the } \\
\text { internal auditors working in } \\
\text { the company }\end{array}$ & 3.98 & .815 & 6 & High \\
\hline 7 & $\begin{array}{l}\text { Internal auditors are primarily } \\
\text { bound by professional } \\
\text { accounting standards }\end{array}$ & 4.16 & .713 & 1 & High \\
\hline Overall Avg & & & & \\
\hline & & & & & \\
\hline
\end{tabular}

We note from the previous table that the general arithmetic mean of the trends of the sample members towards efficiency in terms of relative importance is average, where the arithmetic mean was (4.0273) and with a standard deviation (0.50942). The paragraph (internal auditors are primarily committed to professional accounting standards) ranked first with an arithmetic average (4.16) and with a high relative importance, while the paragraph (a comparison is made between the achieved goals and the goals planned by the internal auditor) ranked last with an arithmetic average (3.96) and with a high relative importance 


\section{Macrothink}

\section{Independence}

Arithmetic averages, standard deviations, ranks and the relative importance of the independence items

\begin{tabular}{|c|c|c|c|c|c|}
\hline \# & Paragraph & SMA & $\begin{array}{l}\text { Standard } \\
\text { Deviation }\end{array}$ & Rank & $\begin{array}{c}\text { Relative } \\
\text { importance }\end{array}$ \\
\hline 1 & $\begin{array}{l}\text { The internal auditors are } \\
\text { appointed with the approval of } \\
\text { the Audit Committee }\end{array}$ & 4.12 & .626 & 1 & High \\
\hline 2 & $\begin{array}{l}\text { Internal auditors report on an } \\
\text { ongoing basis to the Audit } \\
\text { Committee }\end{array}$ & 4.05 & .724 & 3 & High \\
\hline 3 & $\begin{array}{l}\text { The body responsible for } \\
\text { following up the promotion of } \\
\text { internal auditors and following } \\
\text { up on their salaries is the Audit } \\
\text { Committee }\end{array}$ & 4.05 & .713 & 2 & High \\
\hline 4 & $\begin{array}{l}\text { The Audit Committee ensures } \\
\text { that the management does not } \\
\text { hide any information or data } \\
\text { necessary for the performance } \\
\text { of the internal audit functions }\end{array}$ & 3.90 & .745 & 5 & High \\
\hline 5 & $\begin{array}{l}\text { The Audit Committee requests } \\
\text { the Board of Directors to } \\
\text { provide compelling reasons for } \\
\text { not adopting } \\
\text { recommendations of the } \\
\text { internal auditors }\end{array}$ & 3.97 & .770 & 4 & High \\
\hline & Overall Avg & 4.0175 & .54361 & & High \\
\hline
\end{tabular}

We note from the previous table that the general arithmetic mean of the sample members' trends towards independence in terms of relative importance is high, where the arithmetic mean reached (4.0175) and with a standard deviation (0.54361). The paragraph (the internal auditors are appointed with the approval of the Audit Committee) ranked first with a mean (4.12) and with a high relative importance, while the paragraph (the internal auditors continuously submit their reports to the Audit Committee) ranked last with a mean (4.05) and with high relative importance. 


\section{The scope of the internal audit work}

Arithmetic averages, standard deviations, ranks and the relative importance of the paragraphs of the internal audit scope of work

\begin{tabular}{|c|l|c|c|c|c|}
\hline$\#$ & \multicolumn{1}{|c|}{ Paragraph } & SMA & $\begin{array}{c}\text { Standard } \\
\text { Deviation }\end{array}$ & Rank & $\begin{array}{c}\text { Relative } \\
\text { importance }\end{array}$ \\
\hline 1 & $\begin{array}{l}\text { The internal auditor is bound } \\
\text { by the rules, laws and } \\
\text { regulations in force in the } \\
\text { company }\end{array}$ & 4.14 & .742 & 1 & High \\
\hline 2 & $\begin{array}{l}\text { The internal audit function in } \\
\text { the company includes all } \\
\text { activities and operations } \\
\text { related to financial, operational } \\
\text { and administrative matters. }\end{array}$ & 4.05 & .863 & 3 & High \\
\hline 3 & $\begin{array}{l}\text { Weaknesses in the company's } \\
\text { internal audit system are } \\
\text { continuously exposed in order } \\
\text { to ensure that the audit process } \\
\text { is effective. }\end{array}$ & 4.06 & .730 & 2 & High \\
\hline $\begin{array}{l}\text { The company's internal auditor } \\
\text { continuously tests financial, } \\
\text { administrative and operational } \\
\text { information and accounting } \\
\text { systems }\end{array}$ & 4.04 & .708 & 4 & High \\
\hline Overall Avg & $\mathbf{4 . 0 7 5 1}$ & $\mathbf{6 2 2 5 1}$ & & \\
\hline
\end{tabular}

We note from the previous table that the general arithmetic mean of the trends of the sample members towards the scope of the internal audit work in terms of relative importance is high, where the arithmetic mean was (4.0751) and with a standard deviation (0.62251). The paragraph (the internal auditor abides by the laws, laws and regulations in force in the company) ranked first with an arithmetic average of (4.14) and with a high relative importance, while the paragraph (the internal auditor in the company continuously tests financial, administrative and operational information and accounting systems) ranked last With an arithmetic mean (4.04) and a high relative importance.

To compare the dimensions of internal audit quality, the following table has been prepared:

Arithmetic averages, standard deviations, ranks and the relative importance of the dimensions of internal audit quality

\begin{tabular}{|c|c|c|c|c|c|}
\hline$\#$ & The dimension & SMA & $\begin{array}{c}\text { Standard } \\
\text { Deviation }\end{array}$ & Rank & $\begin{array}{c}\text { Relative } \\
\text { importance }\end{array}$ \\
\hline
\end{tabular}




\begin{tabular}{|c|l|c|c|c|c|}
\hline 1 & Efficiency & 4.0273 & .50942 & 1 & High \\
\hline 2 & Independence & 4.0175 & .54361 & 3 & High \\
\hline 3 & Scope of internal audit work & 4.0751 & .62251 & 2 & High \\
\hline \multicolumn{2}{|c|}{ Internal audit quality } & $\mathbf{4 . 0 4 0 0}$ & $\mathbf{. 4 4 9 5 9}$ & & High \\
\hline
\end{tabular}

We note from the previous table that the general average of the dimensions of internal audit quality in terms of relative importance is high, with a general average of 4.0400 and a standard deviation of 0.44959 . The dimension of (the scope of the work of the internal audit) ranked first with a mean of (4.0751) and a standard deviation of (0.62251) and of high relative importance, while the dimension (independence) came in the last place with a mean (4.0175) and a standard deviation (54361.) and of relative importance High.

\section{The modified variable: the characteristics of the CEO}

Arithmetic averages, standard deviations, ranks, and the relative importance of the CEO's characteristics paragraphs

\begin{tabular}{|c|c|c|c|c|c|}
\hline \# & Paragraph & SMA & $\begin{array}{l}\text { Standard } \\
\text { Deviation }\end{array}$ & Rank & $\begin{array}{c}\text { Relative } \\
\text { importance }\end{array}$ \\
\hline 1 & $\begin{array}{l}\text { Older CEOs take more time to } \\
\text { make decisions with the } \\
\text { knowledge they possess. }\end{array}$ & 4.25 & .604 & 2 & High \\
\hline 2 & $\begin{array}{l}\text { Older CEOs tend to prefer } \\
\text { guaranteed profit. }\end{array}$ & 4.20 & .549 & 5 & High \\
\hline 3 & $\begin{array}{l}\text { Older CEOs have more } \\
\text { experience in obtaining and } \\
\text { evaluating information. }\end{array}$ & 4.16 & .659 & 6 & High \\
\hline 4 & $\begin{array}{l}\text { The younger CEOs work on } \\
\text { developing creative changes, } \\
\text { which makes the company } \\
\text { more ahead of its competitors. }\end{array}$ & 4.15 & .651 & 7 & High \\
\hline 5 & $\begin{array}{l}\text { Younger CEOs are investing in } \\
\text { research and development } \\
\text { more than older CEOs }\end{array}$ & 4.21 & .575 & 4 & High \\
\hline 6 & $\begin{array}{l}\text { CEOs with longer tenures in } \\
\text { office usually gain more power } \\
\text { and authority within the } \\
\text { company, which leads to better } \\
\text { performance. }\end{array}$ & 4.15 & .625 & 8 & High \\
\hline 7 & The appointment of the CEO & 4.09 & .623 & 11 & High \\
\hline
\end{tabular}




\begin{tabular}{|c|c|c|c|c|c|}
\hline & $\begin{array}{l}\text { for a long time gives } \\
\text { continuity to the company } \\
\text { because of his understanding } \\
\text { of the company's culture and } \\
\text { operations well. }\end{array}$ & & & & \\
\hline 8 & $\begin{array}{l}\text { The appointment of the Chief } \\
\text { Executive Officer for a long } \\
\text { term would prejudice the } \\
\text { independence of the Board of } \\
\text { Directors. }\end{array}$ & 4.08 & .686 & 12 & High \\
\hline 9 & $\begin{array}{l}\text { The appointment of the CEO } \\
\text { for a long period may build a } \\
\text { relationship with the members } \\
\text { of the Board of Directors, } \\
\text { which affects the objectivity of } \\
\text { the performance evaluation of } \\
\text { the CEO by the Board. }\end{array}$ & 4.03 & .733 & 13 & High \\
\hline 10 & $\begin{array}{l}\text { Female CEOs tend to increase } \\
\text { oversight in the board of } \\
\text { directors. }\end{array}$ & 3.92 & .707 & 15 & High \\
\hline 11 & $\begin{array}{l}\text { Female CEOs differ in the way } \\
\text { they make investment } \\
\text { decisions from male CEOs. }\end{array}$ & 3.97 & .702 & 14 & High \\
\hline 12 & $\begin{array}{l}\text { Male CEOs are more likely to } \\
\text { take risks than female CEOs. }\end{array}$ & 4.26 & .677 & 1 & High \\
\hline 13 & $\begin{array}{l}\text { The compensation structure of } \\
\text { female CEOs is lower than that } \\
\text { of male CEOs }\end{array}$ & 4.13 & .696 & 9 & High \\
\hline 14 & $\begin{array}{l}\text { The scientific qualification of } \\
\text { the CEO has an important role } \\
\text { in increasing the performance } \\
\text { of the company }\end{array}$ & 4.11 & .670 & 10 & High \\
\hline 15 & $\begin{array}{l}\text { CEOs who hold the position of } \\
\text { Chairman of the Board of } \\
\text { Directors or any position } \\
\text { within the company have more } \\
\text { knowledge and experience }\end{array}$ & 4.25 & .622 & 3 & High \\
\hline & Overall Avg & 4.1304 & .38525 & & High \\
\hline
\end{tabular}

We note from the previous table that the general arithmetic mean of the trends of the sample members towards the characteristics of the CEO in terms of relative importance is high, where the arithmetic mean reached (4.1304) with a standard deviation of (.38525). The paragraph (the men CEOs tend to take risks more than women CEOs) ranked first with a 
arithmetic average (4.26) and a high relative importance, while the paragraph (that women CEOs tend to increase oversight in the board of directors) ranked last with an arithmetic average (3.92) with a high relative importance.

\section{The dependent variable: the performance of companies}

\section{Financial performance}

Arithmetic averages, standard deviations, ranks, and the relative importance of the financial performance items

\begin{tabular}{|c|c|c|c|c|c|}
\hline \# & Paragraph & SMA & $\begin{array}{l}\text { Standard } \\
\text { Deviation }\end{array}$ & Rank & $\begin{array}{c}\text { Relative } \\
\text { importance }\end{array}$ \\
\hline 1 & $\begin{array}{l}\text { The company has the ability to } \\
\text { make maximum use of its } \\
\text { available resources, which } \\
\text { contributes to making a profit. }\end{array}$ & 4.05 & .698 & 7 & High \\
\hline 2 & $\begin{array}{l}\text { The company has the ability to } \\
\text { pursue a policy of cost cutting } \\
\text { without compromising its } \\
\text { market share }\end{array}$ & 4.17 & .710 & 2 & High \\
\hline 3 & $\begin{array}{l}\text { The company has the ability to } \\
\text { conduct a cost-reduction } \\
\text { policy without compromising } \\
\text { the quality of its products }\end{array}$ & 4.14 & .720 & 5 & High \\
\hline 4 & $\begin{array}{l}\text { The size of the company's } \\
\text { profits corresponds to the } \\
\text { quality of the products and the } \\
\text { nature of the services it } \\
\text { provides to customers }\end{array}$ & 4.17 & .769 & 3 & High \\
\hline 5 & $\begin{array}{l}\text { The company increases the } \\
\text { wealth of its shareholders and } \\
\text { provides a real return on } \\
\text { investment }\end{array}$ & 4.16 & .697 & 4 & High \\
\hline 6 & $\begin{array}{l}\text { The dividends distributed to } \\
\text { the company's shareholders are } \\
\text { in line with their preferences } \\
\text { and expectations }\end{array}$ & 4.10 & .735 & 6 & High \\
\hline 7 & $\begin{array}{l}\text { The company applies } \\
\text { management methods and } \\
\text { policies that contribute to } \\
\text { increasing the volume of future } \\
\text { cash flows }\end{array}$ & 4.21 & .817 & 1 & High \\
\hline
\end{tabular}




\section{Overall Avg}

\subsection{8}

.47738

High

We note from the previous table that the general arithmetic mean of the sample members' trends towards financial performance in terms of relative importance is average, where the arithmetic mean reached (4.1418) and with a standard deviation of (0.47738). The paragraph (the company applies management methods and policies that contribute to increasing the volume of future cash flows) ranked first with an arithmetic average (4.21) and of high relative importance, while the paragraph (the company has the ability to make maximum use of its available resources, which contributes to achieving profit (4.05) with a high relative importance.

\section{Non-financial performance}

Arithmetic averages, standard deviations, ranks and the relative importance of non-financial performance items

\begin{tabular}{|c|c|c|c|c|c|}
\hline$\#$ & Paragraph & SMA & $\begin{array}{l}\text { Standard } \\
\text { Deviation }\end{array}$ & Rank & $\begin{array}{c}\text { Relative } \\
\text { importance }\end{array}$ \\
\hline 1 & $\begin{array}{l}\text { The company has the ability to } \\
\text { enter new markets in order to } \\
\text { increase its sales }\end{array}$ & 4.01 & .687 & 6 & High \\
\hline 2 & $\begin{array}{l}\text { The company has the ability to } \\
\text { follow sound policies in the } \\
\text { process of collection, } \\
\text { inventory management, and } \\
\text { payment of obligations }\end{array}$ & 4.09 & .665 & 2 & High \\
\hline 3 & $\begin{array}{l}\text { The financial indicators and } \\
\text { ratios that reflect the } \\
\text { company's profits are high } \\
\text { compared to similar companies } \\
\text { in the industry. }\end{array}$ & 4.06 & .673 & 5 & High \\
\hline 4 & $\begin{array}{l}\text { The company has the ability to } \\
\text { keep pace with modern } \\
\text { technology in order to develop } \\
\text { its internal operations }\end{array}$ & 4.09 & .729 & 3 & High \\
\hline 5 & $\begin{array}{l}\text { The company has the ability to } \\
\text { rely on modern and advanced } \\
\text { methods and processes in its } \\
\text { production processes }\end{array}$ & 4.11 & .670 & 1 & High \\
\hline 6 & $\begin{array}{l}\text { The company has the ability to } \\
\text { continuously evaluate its } \\
\text { operational performance to } \\
\text { determine the effectiveness of } \\
\text { operations and address }\end{array}$ & 4.07 & .708 & 4 & High \\
\hline
\end{tabular}




\begin{tabular}{|l|l|l|l|l|}
\hline weaknesses & & & & \\
\hline Overall Avg & $\mathbf{4 . 0 7 0 1}$ & $\mathbf{. 4 6 9 5 6}$ & & High \\
\hline
\end{tabular}

We note from the previous table that the general arithmetic mean of the sample members' trends towards non-financial performance in terms of relative importance is high, as the arithmetic mean reached (4.0701) and with a standard deviation (46956.). The paragraph (the company has the ability to rely on modern and advanced methods and processes in its production processes) ranked first with an arithmetic average (4.11) and a high relative importance, while the paragraph (the company has the ability to enter new markets in order to increase its sales came in the last rank with an average of arithmetic (4.01) and with a high relative importance.

\section{Multi collinearity test}

To test the suitability of the study model for the analysis of linear and hierarchical regression, the phenomenon of multiple linear correlations was tested, as this phenomenon indicates that there is an almost perfect linear correlation between two or more variables, which inflates the value of the determination coefficient $R^{2}$ and makes it greater than its true value. Among the independent variables according to the study model, the results were as follows:

Correlation matrix for independent variables

\begin{tabular}{|c|c|c|c|c|}
\hline The variable & $\begin{array}{c}\text { CEO } \\
\text { Characteristics }\end{array}$ & Efficiency & Independence & $\begin{array}{c}\text { scope of the } \\
\text { work of the } \\
\text { internal audit }\end{array}$ \\
\hline $\begin{array}{c}\text { CEO } \\
\text { Characteristics }\end{array}$ & 1.000 & & & \\
\hline Efficiency & $0.574^{* *}$ & 1.000 & & 1.000 \\
\hline $\begin{array}{c}\text { Independence } \\
\text { scope of the } \\
\text { work of the } \\
\text { internal audit }\end{array}$ & $0.506^{* *}$ & $0.489^{* *}$ & $0.521^{* *}$ & \\
\hline
\end{tabular}

** Indicates a significance level of 0.05

Table shows that the highest correlation coefficient was between the two variables (efficiency) and (the characteristics of the CEO), which is (0.574), which is less than (0.80), and this indicates the absence of the multiple linear correlation phenomenon between the variables, where the value of the correlation coefficient is greater than (0.80) an indication of the existence of the multiple linear correlation problem The Variance Inflation Factor (VIF) test was also used for all independent variables to confirm the previous result, which is the absence of multiple linear correlations, and the results were as follows:

Results of the multiple correlation test between independent variables

\section{Tolerance}

\section{VIF}




\begin{tabular}{|c|c|c|}
\hline 0.535 & 1.869 & CEO Characteristics \\
\hline 0.617 & 1.622 & Efficiency \\
\hline 0.616 & 1.624 & Independence \\
\hline 0.622 & 1.608 & $\begin{array}{c}\text { scope of the work of the } \\
\text { internal audit }\end{array}$ \\
\hline
\end{tabular}

The result of the coefficient of variance inflation test indicates that there is no problem of multiple linear correlation between the study variables, as all values were greater than 1 and less than 10, and the value of (Tolerance) was confined between the number 0.1 and the number 1 .

\section{Testing the hypotheses of the study}

In this section of the study, hypothesis testing will be analyzed, where simple linear regression analysis and hierarchical regression analysis were used, and the results were as follow

\section{The first main hypothesis H01}

There is no impact on the quality of internal auditing on the financial performance of Jordanian corporations. To test and test the first main hypothesis, simple linear regression analysis was used, and the results were as follows:

* Results of testing the first main hypothesis H01

\begin{tabular}{|c|c|c|c|c|c|c|c|c|c|}
\hline \multicolumn{5}{|c|}{ Coefficient } & \multicolumn{2}{|c|}{ ANOVA } & \multicolumn{2}{|c|}{$\begin{array}{c}\text { Model } \\
\text { Summary }\end{array}$} & \multirow[t]{2}{*}{$\begin{array}{c}\text { Dependent } \\
\text { variable }\end{array}$} \\
\hline $\begin{array}{c}\text { Sig t* } \\
\text { Indication } \\
\text { level }\end{array}$ & $\begin{array}{c}\text { Calculated } \\
\mathbf{T}\end{array}$ & $\begin{array}{c}\text { Standard } \\
\text { error }\end{array}$ & B & Statement & $\begin{array}{c}\text { Sig } \mathrm{F}^{*} \\
\text { Indication } \\
\text { level }\end{array}$ & $\begin{array}{c}\text { Calculated } \\
\text { F }\end{array}$ & $\mathrm{R}^{2}$ & $\mathbf{R}$ & \\
\hline 0.000 & 9.959 & 0.063 & 0.0632 & $\begin{array}{c}\text { Internal } \\
\text { audit } \\
\text { quality }\end{array}$ & 0.000 & 99.178 & .354 & .595 & $\begin{array}{c}\text { Financial } \\
\text { performance }\end{array}$ \\
\hline
\end{tabular}

*The effect is statistically significant at the level $(0.05 \geq \alpha)$.

the value of $(\mathrm{R}=0.595)$, which means that there is a positive relationship between (the quality of internal auditing) and (the financial performance). It turns out that the value of the coefficient of determination is $\left(R^{2}=0.354\right)$, which means that (the quality of internal auditing) has explained the amount of $(35.4 \%)$ of the variance, while keeping other factors constant. It also shows that the value of $(\mathrm{F})$ reached $(99.178)$ at a confidence level $(\mathrm{Sig}=0.000)$, and this confirms the regression at the level $(0.05 \geq \alpha)$.

It also appears from the coefficients table that the value of $(\mathrm{B}=0.632)$ was $(\mathrm{T}=9.959)$ at a level of confidence $(\mathrm{Sig}=0.000)$, and this confirms the coefficient at the level $(0.05 \geq \alpha)$.

Based on the above, we reject the first main null hypothesis, and accept the alternative 


\section{Macrothink}

hypothesis.

\section{There is a statistically impact of the quality of internal auditing on the financial performance of Jordanian corporations.}

This result indicates the great role that the quality of internal audit plays in the financial performance of companies, as the quality of internal audit is vital for every organization to achieve effective management of resources, which leads to improved financial performance as a key implementation strategy of the accounting system and helps management to check the functioning of each department within the company as a whole. it indicated that there is a statistically significant impact of the quality of the internal audit on the financial performance of companies.

The second main hypothesis H02: There is no impact on the quality of internal auditing on the non-financial performance of Jordanian corporations.

* The results of testing the second main hypothesis

\begin{tabular}{|c|c|c|c|c|c|c|c|c|c|}
\hline \multicolumn{5}{|c|}{ Coefficient } & \multicolumn{2}{|c|}{ ANOVA } & \multicolumn{2}{|c|}{$\begin{array}{c}\text { Model } \\
\text { Summary }\end{array}$} & \multirow[t]{2}{*}{$\begin{array}{c}\text { Dependent } \\
\text { variable }\end{array}$} \\
\hline $\begin{array}{c}\text { Sig } \mathrm{t}^{*} \\
\text { Indication } \\
\text { level }\end{array}$ & $\begin{array}{c}\text { Calculated } \\
\mathbf{T}\end{array}$ & $\begin{array}{l}\text { Standard } \\
\text { error }\end{array}$ & B & Statement & $\begin{array}{c}\text { Sig } \mathrm{F}^{*} \\
\text { Indication } \\
\text { level }\end{array}$ & $\begin{array}{c}\text { Calculated } \\
\text { F }\end{array}$ & $\mathrm{R}^{2}$ & $\mathbf{R}$ & \\
\hline 0.000 & 9.110 & 0.064 & 0.586 & $\begin{array}{c}\text { Internal } \\
\text { audit } \\
\text { quality }\end{array}$ & 0.000 & 82.985 & .314 & .561 & $\begin{array}{c}\text { Non-Financial } \\
\text { performance }\end{array}$ \\
\hline
\end{tabular}

*The effect is statistically significant at the level $(0.05 \geq \alpha)$.

The results indicate that the value of $(\mathrm{R}=0.561)$, which means that there is a positive relationship (the quality of internal auditing) and (non-financial performance) and it turns out that the value of the coefficient of determination is $\left(R^{2}=0.314\right)$, which means that the quality of the internal audit has explained an amount $(31.4 \%)$ of the variance in (non-financial performance), while keeping other factors constant. It also shows that the value of $(\mathrm{F})$ reached $(82,985)$ at a confidence level $(\mathrm{Sig}=0.000)$, and this confirms the significance of the regression at the level $(0.05 \geq \alpha)$.

It also appears from the coefficients table that the value of $(B=0.586)$ and the value of $(T=$ 9.110) at the level of confidence ( $\mathrm{Sig}=0.000$ ), and this confirms the significance of the coefficient at the level $(0.05 \geq \alpha)$.

Based on the above, we reject the second main null hypothesis and accept the alternative main hypothesis that says:

*There is an impact of the quality of the internal audit on the non-financial performance of the Jordanian corporations.

The third main hypothesis $\mathrm{H} 03$ 


\section{Ml Macrothink}

Journal of Public Administration and Governance ISSN 2161-7104 2022, Vol. 12, No. 1

There is no impact of the quality of internal audit on the financial performance of Jordanian corporations in light of the characteristics of the CEO.

To test the third main hypothesis, hierarchical regression was used, and the results were as follows:

* Results of the hierarchical regression to show the modified role of the CEO's characteristics on the financial performance

\begin{tabular}{|c|c|c|c|c|c|c|c|}
\hline \multicolumn{3}{|c|}{ Step 2} & \multicolumn{3}{|c|}{ Step 1} & \multirow{2}{*}{$\begin{array}{c}\text { Independent } \\
\text { variables }\end{array}$} & \multirow{2}{*}{$\begin{array}{c}\text { Dependent } \\
\text { variable }\end{array}$} \\
\hline Sig $t$ & $\begin{array}{c}\text { Calculated } \\
\mathbf{t}\end{array}$ & B & Sig $t$ & $\begin{array}{c}\text { Calculated } \\
\mathbf{t}\end{array}$ & B & & \\
\hline 0.000 & 5.497 & 0.461 & 0.000 & 9.959 & 0.632 & $\begin{array}{c}\text { Internal audit } \\
\text { quality }\end{array}$ & \multirow{5}{*}{$\begin{array}{c}\text { Financial } \\
\text { performance }\end{array}$} \\
\hline 0.003 & 3.031 & 0.297 & & & & $\begin{array}{c}\text { CEO } \\
\text { Characteristics }\end{array}$ & \\
\hline \multicolumn{3}{|c|}{0.385} & \multicolumn{3}{|c|}{0.354} & $\mathbf{R}^{2}$ & \\
\hline \multicolumn{3}{|c|}{56.428} & \multicolumn{3}{|c|}{99.178} & $\Delta \mathbf{F}$ & \\
\hline \multicolumn{3}{|c|}{0.000} & \multicolumn{3}{|c|}{0.000} & $\operatorname{Sig} \Delta F$ & \\
\hline
\end{tabular}

*The effect is statistically significant at the level $(0.05 \geq \alpha)$.

the results of a hierarchical regression based on two models, as the results of the first model based on the first step reflected a statistically significant impact of the quality of internal auditing on financial performance, where the value was $(\Delta \mathbf{F}=99.178)$ and at a level of significance (Sig $\Delta \mathbf{F} 0.000$ which is less than 0.05 , as it was The value of the coefficient of determination (

$\mathrm{R}^{2}=0.354$ ), and this indicates that the quality of the internal audit explains $35.4 \%$ of the variance in financial performance.

In the second step, the variable (Chief Executive Officer Characteristics) was entered into the regression model, where the value of the coefficient of determination was $\left(R^{2}=0.385\right)$, and it is noted from that an increase in the value of $\mathrm{R}^{2}$ by $(0.031)$, and this increase is statistically significant as the value of $(\Delta F=56.428)$.

And with a level of ( $\operatorname{Sig} \Delta \mathrm{F}=0.000)$, which is less than 0.05 , as was the value of $(\mathrm{B}=0.297)$ at (the characteristics of the CEO), and at a level of significance ( $\mathrm{Sig} t=0.003$ ), and this confirms the positive impact of the CEO characteristics variable on the relationship between the quality of internal auditing and the financial performance of Jordanian corporations.

Accordingly, we conclude that: "there is an impact of the quality of internal auditing on the financial performance of Jordanian corporations in light of the characteristics of the CEO."

This result can be clarified through the role that the CEO's characteristics play in improving and developing the quality of internal auditing, which in turn positively affects the financial 
performance, as well as through the selection of competent internal auditors with expertise who make improvements to the adequacy and effectiveness of financial performance in companies.

\section{The fourth main hypothesis $\mathrm{HO4}$}

There is no impact of the quality of internal audit on the non-financial performance of Jordanian corporations in light of the characteristics of the CEO.

To test the fourth main hypothesis, hierarchical regression was used, and the results were as follows:

* Results of the hierarchical regression to show the modified role of the CEO's characteristics on the Non-financial performance

\begin{tabular}{|c|c|c|c|c|c|c|c|}
\hline \multicolumn{3}{|c|}{ Step 2} & \multicolumn{3}{|c|}{ Step 1} & \multirow{2}{*}{$\begin{array}{c}\text { Independent } \\
\text { variables }\end{array}$} & \multirow{2}{*}{$\begin{array}{c}\text { Dependent } \\
\text { variable }\end{array}$} \\
\hline Sig $t$ & $\begin{array}{c}\text { Calculated } \\
\mathbf{t}\end{array}$ & B & Sig $t$ & $\begin{array}{c}\text { Calculated } \\
t\end{array}$ & B & & \\
\hline 0.000 & 3.817 & 0.312 & 0.000 & 9.110 & 0.586 & $\begin{array}{c}\text { Internal audit } \\
\text { quality }\end{array}$ & \multirow{5}{*}{$\begin{array}{c}\text { Non-Financial } \\
\text { performance }\end{array}$} \\
\hline 0.000 & 4.991 & 0.475 & & & & $\begin{array}{c}\text { CEO } \\
\text { Characteristics }\end{array}$ & \\
\hline \multicolumn{3}{|c|}{0.398} & \multicolumn{3}{|c|}{0.314} & $\mathbf{R}^{2}$ & \\
\hline \multicolumn{3}{|c|}{59.431} & \multicolumn{3}{|c|}{82.985} & $\Delta \mathbf{F}$ & \\
\hline \multicolumn{3}{|c|}{0.000} & \multicolumn{3}{|c|}{0.000} & $\operatorname{Sig} \Delta F$ & \\
\hline
\end{tabular}

*The effect is statistically significant at the level $(0.05 \geq \alpha)$.

the results of a hierarchical regression based on two models, as the results of the first model based on the first step reflected a statistically significant impact of the quality of internal auditing on non-financial performance, where the value was $(\Delta \mathrm{F}=82.985)$. And at the level of significance Sig $\Delta \mathbf{F}=(0.000)$ which is Less than 0.05 , and the value of the coefficient of determination was $\left(\mathrm{R}^{2}=0.314\right)$, and this indicates that the quality of internal audit explains $31.4 \%$ of the discrepancy in non-financial performance.

In the second step, a variable (the characteristics of the CEO) was entered into the regression model, where the value of the coefficient of determination was $\left(\mathrm{R}^{2}=0.398\right)$ and it is noted from this that an increase in the value of $\mathrm{R}^{2}$ increased by (0.084), and this increase is statistically significant, as the value was $(\Delta \mathrm{F}=59.431)$.

And at a level of significance ( $\operatorname{Sig} \Delta \mathrm{F}=0.000$ ), which is less than 0.05 , as was the value of ( $\mathrm{B}$ $=0.475)$ at (characteristics of the CEO), and at a level of significance (Sig $\mathrm{t}=0.000)$, and this confirms the effect the positive variable of the CEO characteristics in the relationship between the quality of internal auditing and the non-financial performance of Jordanian corporations. 


\section{Macrothink}

Journal of Public Administration and Governance

ISSN 2161-7104

2022, Vol. 12, No. 1

Accordingly, we conclude that: "there is an impact of the quality of internal auditing on the non-financial performance of Jordanian corporations in light of the characteristics of the CEO."

Development this result can be clarified through the role that the CEO's characteristics play in the quality of internal audit, which in turn positively affects the non-financial performance.

\section{The results}

By analyzing the study questions and testing its hypotheses, the study reached the following results:

1. The quality of the internal audit positively and importantly affects the financial performance of Jordanian corporations.

2. The quality of the internal audit positively and importantly affects the non-financial performance of Jordanian corporations.

3. The characteristics of the CEO have a significant positive impact on the relationship between the quality of internal auditing and the financial performance of Jordanian corporations.

4. The characteristics of the CEO have a significant positive impact on the non-financial performance of the Jordanian corporations in light of the characteristics of the CEO.

\section{Recommendations}

In this part, the researcher presents a set of suggestions and recommendations that may be useful to the supervisory and management authorities, which contribute to enhancing the role of internal audit quality in the performance of companies, as well as activating the role of the CEO's characteristics. The relationship between internal audit qualities in the performance of companies, both financial and non-financial, including that's the following

The necessity of strengthening and improving the internal audit function in Jordanian companies and working to increase its quality.

The need for companies to improve their performance, both financial and non-financial, by focusing more on the characteristics and attributes of the CEO.

The necessity for companies to keep abreast of developments and technologies related to internal auditing and to use them in internal audit operations in Jordanian corporations.

Carrying out studies similar to this study in other fields such as the service and financial field, this contributes to enhancing the understanding of the role of the chief executive's characteristics in the relationship between the quality of internal auditing and performance, both financial and non-financial.

Conducting other studies on the relationship between the quality of internal auditing and performance, both financial and non-financial, dealing with a modified variable other than the 
characteristics of the CEO, such as organizational culture, organizational climate, or organizational structure.

\section{References}

Abdullah, M. A. M. (2013). The relationship between internal audit quality and profit management practices: an applied theoretical study, Master's thesis, Faculty of Commerce, Tanta University, unpublished.

Abdul-Razzaq, S. M. M. (2015). The role of the internal auditor in activating the risk management system and its repercussions on the financial performance of joint stock companies listed in the stock exchange (study).

Abu, J. A. Y. (2015). The impact of internal auditing on profit management in industrial companies listed on the Amman Stock Exchange. an unpublished master's thesis, Zarqa University, Zarqa, Jordan.

Al-Abed, S. (2015). Advancing the auditing profession towards globalization, the role of the internal audit department in the Central Bank of Jordan. Auditor's Journal, Jordanian Certified Public Accountants Association, first issue.

Ali, H. A. A., \& Al-Johar, K. A. K. (2017). The Impact of Using Six Sigma Technology Standards on Improving the Quality of Internal Auditing. Journal of the Islamic University College, (42), 151-185.

Alshahed, R. M., \& Al-Kurdi, A. A. (2018). The impact of the characteristics of the board of directors and audit committees on the quality of profits, evidence from Jordanian commercial banks. The Jordanian Journal of Applied Science, Human Sciences Series, Irbid, 5(1).

Al-Thneibat, A. A. Q. (2015). Auditing Accounts in the Light of International Standards, Theory and Application. Dar Wael Publishing, Fifth Edition.

Atta (2019). Characteristics of the board of directors and their impact on financial performance: An applied study on industrial companies listed on the Amman Stock Exchange

Boughazy, I., \& Tommy, M. (2018). The contribution of the internal audit function to assessing the internal control system and improving risk management processes for the purpose of activating governance, a field study on active commercial banks in Algeria. Journal of the Economist Researcher (CHEEC), 1(6), 365-391.

Bousalem, A. B., \& Salah, S. (2017). Internal audit within the framework of governance and its role in managing banking risks. Journal of Studies in Economics, Trade and Finance, VI(One), 193-210.

Hadi, A. H. (2017). The strategy of the governance role of internal auditing in risk management in financial institutions, a field study in a sample of Iraqi private banks. Al-Ghari Journal of Economic and Administrative Sciences, IV(II), 800-822. 
Hamdan, N., \& Al-Qudah, A. (2013). The Impact of the Capital Structure on the Performance of Jordanian Banks Listed on the Amman Stock Exchange: An Analytical Study. Al-Manara Journal, 4.

Hamidush, H. (2018). The Role of Internal Audit in Activating Governance in Insurance Companies. Journal of Economics and Human Development, 9(1), 7-19.

Hayrat, H. I. A. (2016). The Impact of the Board's Characteristics on the Quality of Auditing in Industrial Corporations (Applied Study), an unpublished Master's thesis, Faculty of Economics and Administrative Sciences, Jerash University, Jerash, Jordan.

International Arab Society of Certified Accountants. (2015). Publications of International Standards for Quality Control, Auditing, Auditing, and Other Assurance Operations and Related Services, Part One, Central Press, Amman.

Jafari, A., \& Al-Ayeb, Abdul-Rahman, (2017). Theoretical rooting of the impact of integrated internal auditing on improving the strategic performance of the economic institution. Journal of the Research Unit in Human Resources Development, 8(2), 151-173.

Kahlouli, A. B., \& Khair, al-Din M. A. (2018). the role of internal auditing in achieving the quality of accounting information: a case study of the port institution of Skikda. Al-Bahith Al-Eqtisadi Journal, VI(One), 199-224.

Khalil, A., Mahmoud, M., \& Maghribi, M. I. M. (2016). The impact of ownership structures patterns and characteristics of the board of directors on the quality of the online financial report on companies listed on the Egyptian Stock Exchange. Journal of Accounting Thought, Ain Shams University, Egypt, 19(1).

Lakhdar, O. (2017). The nature of the relationship between internal audit quality and corporate governance, risk management and internal control under Standard No. 2100 (nature of work). Journal of Economics, Management and Commercial Sciences, 17, 158-175.

Meziani, N. E., \& El-Khoudari, S. (2010). Regulatory controls for the effectiveness of the internal audit function in the light of international standards of internal auditing. Al-Multaqa. The Eighth National on the Audit Profession in Algeria: Reality and Prospects in the Light of Contemporary Global Developments, Faculty of Economics and Management Sciences. University of August 20, 1955 - Skikda, Algeria.

Mona, K., \& Tijani, B. (2017). The Modern Roles of Internal Auditing in the Light of New Developments in the International Reference Framework for Professional Practices. Economic Visions Journal, Martyr Hama Lakhdar University, 2(7), 319-335.

Mubaraki, N., \& Bons, H. (2018). the impact of the characteristics of the board of directors on the financial performance of the institution (case study: a sample of the French institutions listed in the $\mathrm{CaC} 40$ index), economics and management sciences, Department of Economics, Oum El Bouaghi University, Algeria. 


\section{Macrothink}

Journal of Public Administration and Governance ISSN 2161-7104 2022, Vol. 12, No. 1

Nagaz, A. (2018). A Study of the Dimensions of Benefiting from the Work of the Internal Auditor in the Light of the International Standard on Auditing 610. Journal of Economic Issue Studies, University of Laghouat, 15(1), 215-229.

Nawal, S. (2016). Internal auditing is an introduction to risk management in light of the new trend of international standards, a case study of a group of companies in the Algerian east. Journal of Industrial Economics, 11, 189-213.

Radi, N. H. (2010). Analysis of the factors affecting audit quality (analytical study of opinions from a sample of auditors at Al-Qadisiyah University), an unpublished master's thesis, Al-Qadisiyah University, College of Administration and Economics, Iraq.

Sahli, M. Y., \& Kasri, A. (2017). The effect of applying internal auditing on activating corporate governance, a field study in Saidal Company. Al-Quds Open University Journal for Research and Administrative and Economic Studies, 2(7), 74-84.

Suleiman, M. D., \& Al-Hakim, A. A. (2015). The role of total quality management and its impact on the development of human resources in productive organizations, a case study of the Dal Group of Companies (Seqa - Kabo). Journal of Total Quality Management, 16(1).

Zureikat, Q. M., \& Zureikat, O. M. (2010). The reality of performance measures in Jordanian commercial banks, an exploratory study based on the balanced scorecard methodology, Journal of Financial and Commercial Research, Issue One, Port Said University, Faculty of Commerce.

\section{Copyright Disclaimer}

Copyright for this article is retained by the author(s), with first publication rights granted to the journal.

This is an open-access article distributed under the terms and conditions of the Creative Commons Attribution license (http://creativecommons.org/licenses/by/4.0/). 